\title{
Front Matter: Volume 7962
}

, "Front Matter: Volume 7962," Proc. SPIE 7962, Medical Imaging 2011: Image Processing, 796201 (21 April 2011); doi: 10.1117/12.895486 SPIE. Event: SPIE Medical Imaging, 2011, Lake Buena Vista (Orlando), Florida, 


\title{
PROGRESS IN BIOMEDICAL OPTICS AND IMAGING
}

Vol. 12, No. 31

\section{Medical Imaging 2011 Image Processing}

\author{
Benoit M. Dawant \\ David R. Haynor \\ Editors
}

\author{
14-16 February 2011 \\ Lake Buena Vista, Florida, United States
}

Sponsored by

SPIE

Cosponsored by

Dynasil Corporation/RMD Research (United States) - AAPM-American Association of Physicists in Medicine (United States) - DQE Instruments, Inc. (Canada) • Ocean Thin Films, Inc. (United States) - CREOL-The College of Optics and Photonics, Univ. of Central Florida (United States) VIDA Diagnostics, Inc. (United States)

Cooperating Organizations

AAPM-American Association of Physicists in Medicine (United States) • APS-American Physiological Society (United States) • CARS—Computer Assisted Radiology and Surgery (Germany) - The Society for Imaging Science and Technology • Medical Image Perception Society (United States) • Radiological Society of North America (United States) - Society for Imaging Informatics in Medicine (United States) • SML-The Society for Molecular Imaging The DICOM Standards Committee (United States)

Published by

SPIE

Part One of Two Parts

Volume 7962

Proceedings of SPIE, 1605-7422, v. 7962

SPIE is an international society advancing an interdisciplinary approach to the science and application of light. 
The papers included in this volume were part of the technical conference cited on the cover and title page. Papers were selected and subject to review by the editors and conference program committee. Some conference presentations may not be available for publication. The papers published in these proceedings reflect the work and thoughts of the authors and are published herein as submitted. The publisher is not responsible for the validity of the information or for any outcomes resulting from reliance thereon.

Please use the following format to cite material from this book:

Author(s), "Title of Paper," in Medical Imaging 2011: Image Processing, edited by Benoit M. Dawant, David R. Haynor, Proceedings of SPIE Vol. 7962 (SPIE, Bellingham, WA, 2011) Article CID Number.

ISSN $1605-7422$

ISBN 9780819485045

Published by

SPIE

P.O. Box 10, Bellingham, Washington 98227-0010 USA

Telephone +1 3606763290 (Pacific Time) · Fax +1 3606471445

SPIE.org

Copyright (C) 2011, Society of Photo-Optical Instrumentation Engineers.

Copying of material in this book for internal or personal use, or for the internal or personal use of specific clients, beyond the fair use provisions granted by the U.S. Copyright Law is authorized by SPIE subject to payment of copying fees. The Transactional Reporting Service base fee for this volume is $\$ 18.00$ per article (or portion thereof), which should be paid directly to the Copyright Clearance Center (CCC), 222 Rosewood Drive, Danvers, MA 01923. Payment may also be made electronically through CCC Online at copyright.com. Other copying for republication, resale, advertising or promotion, or any form of systematic or multiple reproduction of any material in this book is prohibited except with permission in writing from the publisher. The CCC fee code is 1605 $7422 / 11 / \$ 18.00$.

Printed in the United States of America.

Publication of record for individual papers is online in the SPIE Digital Library.

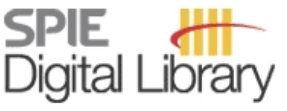

SPIEDigitallibrary.org

Paper Numbering: Proceedings of SPIE follow an e-First publication model, with papers published first online and then in print and on CD-ROM. Papers are published as they are submitted and meet publication criteria. A unique, consistent, permanent citation identifier (CID) number is assigned to each article at the time of the first publication. Utilization of CIDs allows articles to be fully citable as soon they are published online, and connects the same identifier to all online, print, and electronic versions of the publication. SPIE uses a six-digit CID article numbering system in which:

- The first four digits correspond to the SPIE volume number.

- The last two digits indicate publication order within the volume using a Base 36 numbering system employing both numerals and letters. These two-number sets start with 00, 01, 02, 03, 04, $05,06,07,08,09,0 A, 0 B \ldots$. 0Z, followed by 10-1Z, 20-2Z, etc.

The CID number appears on each page of the manuscript. The complete citation is used on the first page, and an abbreviated version on subsequent pages. Numbers in the index correspond to the last two digits of the six-digit CID number. 


\title{
Contents
}

\section{Part One}

\author{
xxi Conference Committee
}

\section{SESSION 1 KEYNOTE AND SEGMENTATION I}

796203 Comparison of fuzzy connectedness and graph cut segmentation algorithms [7962-02] K. C. Ciesielski, West Virginia Univ. (United States) and The Univ. of Pennsylvania (United States); J. K. Udupa, The Univ. of Pennsylvania (United States); A. X. Falcão, P. A. V. Miranda, Univ. Estadual de Campinas (Brazil)

796204 Automated multimodality concurrent classification for segmenting vessels in 3D spectral OCT and color fundus images [7962-03]

Z. Hu, The Univ. of lowa (United States); M. D. Abràmoff, The Univ. of lowa (United States) and lowa City VA Medical Ctr. (United States); M. Niemeijer, The Univ. of lowa (United States); M. K. Garvin, The Univ. of lowa (United States) and lowa City VA Medical Ctr. (United States)

\section{SESSION 2 CARDIAC APPLICATIONS}

796205 Simultaneous detection of landmarks and key-frame in cardiac perfusion MRI using a joint spatial-temporal context model [7962-04]

X. LU, H. Xue, M.-P. Jolly, C. Guetter, Siemens Corp. Research (United States); P. Kellman, L.-Y. Hsu, A. Arai, National Institutes of Health (United States); S. Zuehlsdorff, Siemens Medical Solutions (United States); A. Littmann, Siemens AG (Germany); B. Georgescu, J. Guehring, Siemens Corp. Research (United States)

796206 Statistical fusion of continuous labels: identification of cardiac landmarks [7962-05] F. Xing, S. Soleimanifard, J. L. Prince, The Johns Hopkins Univ. (United States); B. A. Landman, Johns Hopkins Univ. (United States) and Vanderbilt Univ. (United States)

796207 Automated planning of ablation targets in atrial fibrillation treatment [7962-06] J. Keustermans, Katholieke Univ. Leuven (Belgium); S. De Buck, H. Heidbüchel, Univ. Hospital of Gasthuisberg (Belgium); P. Suetens, Katholieke Univ. Leuven (Belgium)

796208 Groupwise registration of cardiac perfusion MRI sequences using normalized mutual information in high dimension [7962-07]

S. Hamrouni, N. Rougon, TELECOM SudParis, CNRS UMR (France); F. Prêteux, Mines ParisTech (France) 
796209 A comparison of cost functions for data-driven motion estimation in myocardial perfusion SPECT imaging [7962-08]

J. M. Mukherjee, P. H. Pretorius, K. L. Johnson, Univ. of Massachusetts Medical School (United States); B. F. Hutton, Univ. College London (United Kingdom); M. A. King, Univ. of Massachusetts Medical School (United States)

7962 0A Automatic evaluation of the Valsalva sinuses from cine-MRI [7962-09]

C. Blanchard, T. Sliwa, A. Lalande, P. Mohan, O. Bouchot, Y. Voisin, Univ. de Bourgogne (France)

\section{SESSION 3 SKELETAL AND ORTHOPEDIC APPLICATIONS}

7962 OB A variational approach to bone segmentation in CT images [7962-10]

J. Calder, Queen's Univ. (Canada); A. M. Tahmasebi, Univ. of Toronto (Canada);

A.-R. Mansouri, Queen's Univ. (Canada)

7962 OC Fully automatic detection of the vertebrae in 2D CT images [7962-11]

F. Graf, H.-P. Kriegel, M. Schubert, M. Strukelj, Ludwig-Maximilians-Univ. München (Germany);

A. Cavallaro, Imaging Science Institute Erlangen (Germany)

7962 OD Segmentation of vertebral bodies in CT and MR images based on 3D deterministic models [7962-12]

D. Štern, T. Vrtovec, F. Pernuš, B. Likar, Univ. of Ljubljana (Slovenia)

7962 OE Manifold learning for automatically predicting articular cartilage morphology in the knee with data from the osteoarthritis initiative (OAI) [7962-13]

C. Donoghue, Imperial College London (United Kingdom); A. Rao, GlaxoSmithKline (United Kingdom); A. M. J. Bull, D. Rueckert, Imperial College London (United Kingdom)

7962 OF Determination of vertebral pose in 3D by minimization of vertebral asymmetry [7962-14]

T. Vrtovec, F. Pernuš, B. Likar, Univ. of Ljubljana (Slovenia)

7962 OG Femur specific polyaffine model to regularize the log-domain demons registration [7962-15] C. Seiler, Univ. Bern (Switzerland) and INRIA Sophia Antipolis (France); X. Pennec, INRIA Sophia Antipolis (France); L. Ritacco, Hospital Italiano de Buenos Aires (Argentina); M. Reyes, Univ. Bern (Switzerland)

$7962 \mathrm{OH}$ Segmentation of knee joints in x-ray images using decomposition-based sweeping and graph search [7962-16]

J. Mu, X. Liu, Univ. of Notre Dame (United States); S. Luan, P. H. Heintz, G. W. Mlady, The Univ. of New Mexico (United States); D. Z. Chen, Univ. of Notre Dame (United States)

\section{SESSION 4 2D IMAGE ANALYSIS}

7962 Ol Integrated segmentation of cellular structures [7962-17]

P. Ajemba, Y. Al-Kofahi, R. Scott, M. Donovan, G. Fernandez, Aureon Biosciences, Inc.

(United States) 
7962 0J Identification and classification of cells in multi-spectral microscopy images of lymph nodes [7962-18]

X. Liu, Univ. of Notre Dame (United States); A. F. Setiadi, Stanford Univ. (United States);

M. S. Alber, Univ. of Notre Dame (United States); P. P. Lee, Stanford Univ. (United States);

D. Z. Chen, Univ. of Notre Dame (United States)

7962 OK Development of a stained cell nuclei counting system [7962-19]

N. Timilsina, C. Moffatt, K. Okada, San Francisco State Univ. (United States)

$7962 \mathrm{OL}$ Texture analysis of clinical radiographs using radon transform on a local scale for differentiation between post-menopausal women with and without hip fracture [7962-20] H. F. Boehm, M. Körner, B. Baumert, U. Linsenmaier, M. Reiser, Ludwig-Maximilians-Univ. München (Germany)

7962 0M Detection of rheumatoid arthritis using infrared imaging [7962-21]

M. Frize, Carleton Univ. (Canada) and Univ. of Ottawa (Canada); C. Adéa, Carleton Univ. (Canada); P. Payeur, Univ. of Ottawa (Canada); G. Di Primio, The Ottawa Hospital (Canada); J. Karsh, The Ottawa Hospital (Canada); A. Ogungbemile, Carleton Univ. (Canada)

\section{SESSION 5 BRAIN STRUCTURE AND DTI}

$7962 \mathrm{ON} \quad$ Identifying intrasulcal medial surfaces for anatomically consistent reconstruction of the cerebral cortex [7962-22]

S. Osechinskiy, F. Kruggel, Univ. of California, Irvine (United States)

796200 Detection and mapping of delays in early cortical folding derived from in utero MRI [7962-23]

P. A. Habas, V. Rajagopalan, J. A. Scott, K. Kim, Univ. of California, San Francisco (United States); A. Roosta, Univ. of California, San Francisco (United States) and Univ. of California, Berkeley (United States); F. Rousseau, LSIIT, CNRS, Univ. of Strasbourg (France);

A. J. Barkovich, O. A. Glenn, C. Studholme, Univ. of California, San Francisco (United States)

7962 OP Topologically correct cortical segmentation using Khalimsky's cubic complex framework [7962-24]

M. J. Cardoso, M. J. Clarkson, M. Modat, Univ. College London (United Kingdom); H. Talbot, M. Couprie, Univ. Paris-Est, CNRS, ESIEE (France); S. Ourselin, Univ. College London (United Kingdom)

$79620 Q \quad$ A novel Riemannian metric for analyzing HARDI data [7962-25]

S. Ncube, A. Srivastava, The Florida State Univ. (United States)

7962 OR Resolving complex fibre configurations using two-tensor random-walk stochastic algorithms [7962-26]

N. Ratnarajah, Univ. of Kent (United Kingdom); A. Simmons, King's College London (United Kingdom); A. Colchester, A. Hojjatoleslami, Univ. of Kent (United Kingdom) 
7962 OS Efficient, graph-based white matter connectivity from orientation distribution functions via multi-directional graph propagation [7962-27]

A. Boucharin, I. Oguz, C. Vachet, Y. Shi, The Univ. of North Carolina at Chapel Hill (United States); M. Sanchez, Emory Univ. (United States); M. Styner, The Univ. of North Carolina at Chapel Hill (United States)

\section{SESSION 6 REGISTRATION I}

7962 OT Landmark-driven parameter optimization for non-linear image registration [7962-28] A. Schmidt-Richberg, R. Werner, J. Ehrhardt, J.-C. Wolf, H. Handels, Univ. zu Lübeck (Germany)

7962 OU Temporal subtraction of chest radiographs compensating pose differences [7962-29] J. von Berg, Philips Research Labs. (Germany); J. Dworzak, Konrad-Zuse-Zentrum für Informationstechnik Berlin (Germany); T. Klinder, Philips Research North America (United States); D. Manke, Philips Healthcare (Germany); A. Kreth, Leibniz Univ. Hannover (Germany); H. Lamecker, S. Zachow, Konrad-Zuse-Zentrum für Informationstechnik Berlin (Germany); C. Lorenz, Philips Research Labs. (Germany)

7962 OV An accurate 3D shape context based non-rigid registration method for mouse whole-body skeleton registration [7962-30]

D. Xiao, Commonwealth Scientific and Industrial Research Organisation (Australia);

D. Zahra, Australian Nuclear Science and Technology Organisation (Australia); P. Bourgeat, Commonwealth Scientific and Industrial Research Organisation (Australia); P. Berghofer, Australian Nuclear Science and Technology Organisation (Australia); O. Acosta Tamayo, Univ. de Rennes 1 (France); C. Wimberley, M. C. Gregoire, Australian Nuclear Science and Technology Organisation (Australia); O. Salvado, Commonwealth Scientific and Industrial Research Organisation (Australia)

7962 OW Iterative closest point algorithm with anisotropic weighting and its application to fine surface registration [7962-31]

L. Maier-Hein, T. R. dos Santos, A. M. Franz, H.-P. Meinzer, German Cancer Research Ctr. (Germany); J. M. Fitzpatrick, Vanderbilt Univ. (United States)

7962 OX Incorporating hard constraints into non-rigid registration via nonlinear programming [7962-32]

D. V. N. Luong, D. Rueckert, B. Rustem, Imperial College London (United Kingdom)

\section{SESSION 7 SHAPE METHODS AND APPLICATIONS}

7962 OY Mapping the distance between the brain and the inner surface of the skull and their global asymmetries [7962-33]

M. Fournier, B. Combès, INSERM, IRISA-INRIA (France); N. Roberts, Queen's Medical Research Institute (United Kingdom); J. Braga, Paul Sabatier Univ. (United Kingdom); S. Prima, INSERM, IRISA-INRIA (France) 
$79620 Z$ Mandible shape modeling using the second eigenfunction of the Laplace-Beltrami operator [7962-34]

S. Seo, Seoul National Univ. (Korea, Republic of); M. K. Chung, Seoul National Univ. (Korea, Republic of) and Waissman Lab. for Brain Imaging and Behavior (United States) and Univ. of Wisconsin (United States); B. J. Whyms, H. K. Vorperian, Univ. of Wisconsin (United States)

796210 Manifold learning for image-based breathing gating in MRI [7962-35]

M. Yigitsoy, C. Wachinger, N. Navab, Technische Univ. München (Germany)

$796211 \quad$ Active shape models unleashed [7962-36]

M. Kirschner, S. Wesarg, Technische Univ. Darmstadt (Germany)

796212 Automatic shape based deformable registration of multiphase contrast enhanced liver CT volumes [7962-37]

M. Erdt, Fraunhofer-Institut für Graphische Datenverarbeitung (Germany); G. Sakas, Technische Univ. Darmstadt (Germany); M. Hammon, Univ. Erlangen (Germany); S. De Beni, Esaote (Italy); L. Solbiati, General Hospital of Busto Arsizio (Italy);

A. Cavallaro, Univ. Erlangen (Germany)

796213 Real-time cardiac surface tracking from sparse samples using subspace clustering and maximum-likelihood linear regressors [7962-38]

V. Singh, A. H. Tewfik, Univ. of Texas at Austin (United States)

\section{SESSION 8 SEGMENTATION II}

796214 A novel adaptive scoring system for segmentation validation with multiple reference masks [7962-39]

J. H. Moltz, J. Rühaak, H. K. Hahn, H.-O. Peitgen, Fraunhofer MEVIS (Germany)

796215 Automatic model-based 3D segmentation of the breast in MRI [7962-40]

C. Gallego, A. L. Martel, Univ. of Toronto (Canada) and Sunnybrook Health Sciences Ctr. (Canada)

796216 Fully automatic segmentation of complex organ systems: example of trachea, esophagus and heart segmentation in $\mathrm{CT}$ images [7962-41]

C. Meyer, J. Peters, J. Weese, Philips Research Labs. (Germany)

796217 Automatic identification of cochlear implant electrode arrays for post-operative assessment [7962-42]

J. H. Noble, T. A. Schuman, Vanderbilt Univ. (United States); C. G. Wright, Southwestern Univ. (United States); R. F. Labadie, B. M. Dawant, Vanderbilt Univ. (United States)

796218 Prostate segmentation with local binary patterns guided active appearance models [7962-43]

S. Ghose Univ. de Girona (Spain) and Le2i-UMR, CNRS, Univ. de Bourgogne (France); A. Oliver, R. Martí, X. Lladó, J. Freixenet, Univ. de Girona (Spain); J. C. Vilanova, Clínica Girona (Spain); F. Meriaudeau, Le2i-UMR, CNRS, Univ. de Bourgogne (France) 
796219 Probabilistic framework for subject-specific and population-based analysis of longitudinal changes and disease progression in brain MR images [7962-44]

A. Ribbens, J. Hermans, F. Maes, D. Vandermeulen, P. Suetens, Katholieke Univ. Leuven (Belgium)

7962 1A A novel local-phase method of automatic atlas construction in fetal ultrasound [7962-45] S. Fathima, S. Rueda, A. Papageorghiou, J. A. Noble, Univ. of Oxford (United Kingdom)

7962 1B Atlas selection strategy in multi-atlas segmentation propagation with locally weighted voting using diversity-based MMR re-ranking [7962-46]

K. Shen, Australian e-Health Research Ctr. (Australia) and Le2i-UMR, CNRS, Univ. de Bourgogne (France); P. Bourgeat, Australian e-Health Research Ctr. (Australia);

F. Meriaudeau, Le2i-UMR, CNRS, Univ. de Bourgogne (France); O. Salvado, Australian e-Health Research Ctr. (Australia)

7962 1C Multi-modal surface comparison and its application to intra-operative range data [7962-47] T. R. dos Santos, A. Seitel, T. Kilgus, T. Heimann, R. Tetzlaff, H. Meinzer, L. Maier-Hein, German Cancer Research Ctr. (Germany)

7962 1D Distance transforms in multichannel MR image registration [7962-48] M. Chen, A. Carass, J. Bogovic, P.-L. Bazin, J. L. Prince, The Johns Hopkins Univ. (United States)

7962 1E Validation of histology image registration [7962-49]

R. Shojaii, Univ. of Toronto (Canada) and Sunnybrook Health Sciences Ctr. (Canada); T. Karavardanyan, Sunnybrook Health Sciences Ctr. (Canada); M. Yaffe, A. L. Martel, Univ. of Toronto (Canada) and Sunnybrook Health Sciences Ctr. (Canada)

\section{SESSION 10 IMAGE ENHANCEMENT/CLASSIFICATION}

7962 IF Intensity inhomogeneity correction of magnetic resonance images using patches [7962-50] S. Roy, A. Carass, P.-L. Bazin, J. L. Prince, The Johns Hopkins Univ. (United States)

$79621 \mathrm{G}$ Initial evaluation of virtual un-enhanced imaging derived from fast $\mathrm{kVp}$-switching dual energy contrast enhanced $\mathrm{CT}$ for the abdomen [7962-51]

M. Joshi, GE Healthcare (United States); P. Mendonca, GE Global Research Ctr. (United States); D. Okerlund, P. Lamb, GE Healthcare (United States); N. Kulkarni, D. Pinho, D. Sahani, Massachusetts General Hospital (United States); R. Bhotika, GE Global Research Ctr. (United States)

$7962 \mathrm{1H}$ A neural network learned information measures for heart motion abnormality detection [7962-52]

M. S. Nambakhsh, Robarts Research Institute (Canada) and Univ. of Western Ontario (Canada); K. Punithakumara, GE Healthcare (Canada) and St. Joseph Health Care (Canada); I. Ben Ayed, St. Joseph Health Care (Canada); A. Goela, Univ. of Western Ontario (Canada); A. Islam, Univ. of Western Ontario (Canada) and St. Joseph Health Care (Canada); T. Peters, Robarts Research Institute (Canada) and Univ. of Western Ontario (Canada); S. Li, Univ. of Western Ontario (Canada) and GE Healthcare (Canada) 
796211 Content-based image retrieval utilizing explicit shape descriptors: applications to breast MRI and prostate histopathology [7962-53]

R. Sparks, A. Madabhushi, Rutgers Univ. (United States)

$79621 \mathrm{~J}$ Amplitude remapping as a step towards standardizing the analysis of MR-images [7962-170]

M. Frommert, Univ. de Genèva (Switzerland) and Max-Planck-Institut für Astrophysik (Germany); I. Sidorenko, Max-Planck-Institut für extraterrestrische Physik (Germany); J. Bauer, D. Müller, E. Rummeny, Technische Univ. München (Germany); F. Eckstein, Paracelsus Medizinische Privatuniversität (Austria); R. Monetti, C. Raeth, Max-Planck-Institut für extraterrestrische Physik (Germany)

SESSION 11 SEGMENTATION OF VASCULAR IMAGES

$79621 \mathrm{~K} \quad$ Machine learning based vesselness measurement for coronary artery segmentation in cardiac CT volumes [7962-55]

Y. Zheng, M. Loziczonek, B. Georgescu, S. K. Zhou, Siemens Corp. Research (United States); F. Vega-Higuera, Siemens Medical Solutions GmbH (Germany); D. Comaniciu, Siemens Corp. Research (United States)

$79621 \mathrm{~L} \quad$ Automated vasculature extraction from placenta images [7962-56] N. Almoussa, B. Dutra, Univ. of California, Los Angeles (United States); B. Lampe, Harvey Mudd College (United States); P. Getrever, T. Wittman, Univ. of California, Los Angeles (United States); C. Salafia, Placental Analytics, LLC (United States); L. Vese, Univ. of California, Los Angeles (United States)

$79621 \mathrm{M}$ Level set based vessel segmentation accelerated with periodic monotonic speed function [7962-57]

C. Wang, Linköping Univ. (Sweden); H. Frimmel, Uppsala Univ. (Sweden); Ö. Smedby, Linköping Univ. (Sweden)

$79621 \mathrm{~N}$ Multispectral MRI centerline tracking in carotid arteries [7962-58]

H. Tang, Erasmus MC (Netherlands) and Technische Univ. Delft (Netherlands); T. van Walsum, R. S. van Onkelen, S. Klein, R. Hameeteman, M. Schaap, Q. J. A. van den Bouwhuijsen, J. C. M. Witteman, A. van der Lugt, Erasmus MC (Netherlands); L. J. van Vliet, Technische Univ. Delft (Netherlands); W. J. Niessen, Erasmus MC (Netherlands) and Technische Univ. Delft (Netherlands)

796210 CARES: Completely Automated Robust Edge Snapper for carotid ultrasound IMT measurement on a multi-institutional database of 300 images: a two stage system combining an intensity-based feature approach with first order absolute moments [7962-59] F. Molinari, Politecnico di Torino (Italy); R. Acharya, Ngee Ann Polytechnic (Singapore); G. Zeng, Mayo Clinic (United States); J. S. Suri, Biomedical Technologies, Inc. (United States) and Idaho State Univ. (United States)

7962 IP Gradient-based 3D-2D registration of cerebral angiograms [7962-60]

U. Mitrović, Univ. of Ljubljana (Slovenia); P. Markelj, B. Likar, Univ. of Ljubljana (Slovenia) and Sensum Computer Vision Systems (Slovenia); Z. Miloševič, Univ. of Ljubljana (Slovenia);

F. Pernuš, Univ. of Ljubljana (Slovenia) and Sensum Computer Vision Systems (Slovenia) 
$79621 Q \quad$ Log-Euclidean free-form deformation [7962-61]

M. Modat, G. R. Ridgway, P. Daga, M. J. Cardoso, D. J. Hawkes, J. Ashburner, S. Ourselin, Univ. College London (United Kingdom)

7962 IR Correspondence estimation from non-rigid motion information [7962-62]

J. Wulff, RWTH Aachen Univ. (Germany) and Univ. of Canterbury (New Zealand); T. Lotz, Univ. of Canterbury (New Zealand); T. Stehle, T. Aach, RWTH Aachen Univ. (Germany);

J. G. Chase, Univ. of Canterbury (New Zealand)

7962 is Co-registration of high resolution MRI sub-volumes in non-human primates [7962-63] J. Lecoeur, Vanderbilt Univ. (United States); F. Wang, L. M. Chen, Vanderbilt Univ. Medical Ctr. (United States); R. Li, Vanderbilt Univ. (United States); M. J. Avison, Vanderbilt Univ. Medical Ctr. (United States); B. M. Dawant, Vanderbilt Univ. (United States)

7962 iT Motion analysis for duplicate frame removal in wireless capsule endoscope [7962-64] H.-G. Lee, M.-K. Choi, S.-C. Lee, Inha Univ. (Korea, Republic of)

$79621 \mathrm{U}$ Fully automated prone-supine coregistration in computed tomographic colonography [7962-65]

B. J. Davis, J. A. Norris, J. Y. Bieszczad, Creare Inc. (United States); J. A. Soto, Boston Univ. Medical Ctr. (United States); D. B. Kynor, Creare Inc. (United States)

$79621 \mathrm{~V}$ Local rigid registration for multimodal texture feature extraction from medical images [7962-66]

S. Steger, Fraunhofer-Institut für Graphische Datenverarbeitung (Germany)

7962 IW Registration of multi-view apical 3D echocardiography images [7962-67]

H. W. Mulder, M. van Stralen, Univ. Medical Ctr. Utrecht (Netherlands); H. B. van der Zwaan, K. Y. E. Leung, J. G. Bosch, Erasmus Univ. Medical Ctr. (Netherlands); J. W. Pluim, Univ. Medical Ctr. Utrecht (Netherlands)

$79621 \mathrm{X} \quad$ Robust linear registration of $\mathrm{CT}$ images using random regression forests [7962-68] E. Konukoglu, A. Criminisi, Microsoft Research Cambridge (United Kingdom); S. Pathak, Microsoft Corp. (United States); D. Robertson, Microsoft Research Cambridge (United Kingdom); S. White, Microsoft Corp. (United States); D. Haynor, Univ. of Washington (United States); K. Siddiqui, Microsoft Corp. (United States)

$79621 \mathrm{Y}$ Ridge-based retinal image registration algorithm involving OCT fundus images [7962-69] Y. Li, G. Gregori, R. W. Knighton, Bascom Palmer Eye Institute, Univ. of Miami Miller School of Medicine (United States); B. J. Lujan, Univ. of California Berkeley (United States); P. J. Rosenfeld, B. L. Lam, Bascom Palmer Eye Institute, Univ. of Miami Miller School of Medicine (United States)

$79621 \mathrm{~A}$ A 2D to 3D ultrasound image registration algorithm for robotically assisted laparoscopic radical prostatectomy [7962-70]

M. Esteghamatian, Robarts Research Institute (Canada) and The Univ. of Western Ontario (Canada); S. E. Pautler, The Univ. of Western Ontario (Canada) and Canadian Surgical Technologies \& Advanced Robotics London (Canada); C. A. McKenzie, T. M. Peters, Robarts Research Institute (Canada) and The Univ. of Western Ontario (Canada) 
796220 Multimodal image registration by edge attraction and regularization using a B-spline grid [7962-71]

A. Klein, D. J. Kroon, Univ. of Twente (Netherlands); Y. Hoogeveen, L. J. Schultze Kool, W. K. J. Renema, Radboud Univ. Nijmegen Medical Ctr. (Netherlands); C. H. Slump, Univ. Twente (Netherlands)

$796221 \quad$ Non-rigid registration of multiphoton microscopy images using B-splines [7962-72] K. S. Lorenz, Purdue Univ. (United States); P. Salama, Indiana Univ.-Purdue Univ. Indianapolis (United States); K. W. Dunn, Indiana Univ. (United States); E. J. Delp, Purdue Univ. (United States)

796222 Efficient registration method of medical images using GPU [7962-73]

T. Kurihara, K. Matsuzaki, K. Seto, Y. Nagamine, Hitachi, Ltd. (Japan)

796223 Evaluation of optimization methods for intensity-based 2D-3D registration in $\mathrm{x}$-ray guided interventions [7962-74]

I. M. J. van der Bom, Univ. of Massachusetts Medical School (United States); S. Klein, Erasmus MC (Netherlands); M. Staring, Leiden Univ. Medisch Ctr. (Netherlands); R. Homan, Philips Healthcare (Netherlands); L. W. Bartels, J. P. W. Pluim, Univ. Medical Ctr. Utrecht (Netherlands)

POSTER SESSION: ATLASES

796224 Evaluation of multi atlas-based approaches for the segmentation of the thyroid gland in IMRT head-and-neck CT images [7962-75]

A. Chen, Vanderbilt Univ. (United States); K. J. Niermann, M. A. Deeley, Vanderbilt-Ingram Cancer Ctr. (United States); B. M. Dawant, Vanderbilt Univ. (United States)

796225 Automatic skull-stripping of rat MRI/DTI scans and atlas building [7962-76]

I. Oguz, J. Lee, F. Budin, A. Rumple, M. McMurray, Univ. of North Carolina at Chapel Hill (United States) C. Ehlers, The Scripps Research Institute (United States); F. Crews, J. Johns, M. Styner, Univ. of North Carolina at Chapel Hill (United States)

796226 Evaluating and improving label fusion in atlas-based segmentation using the surface distance [7962-77]

T. R. Langerak, U. A. van der Heide, A. Kotte, F. F. Berendsen, J. P. W. Pluim, Univ. Medical Ctr. Utrecht (Netherlands)

796227 Group-wise automatic mesh-based analysis of cortical thickness [7962-78]

C. Vachet, H. Cody Hazlett, M. Niethammer, I. Oguz, Univ. of North Carolina at Chapel Hill (United States); J. Cates, R. Whitaker, Univ. of Utah (United States); J. Piven, M. Styner, Univ. of North Carolina at Chapel Hill (United States)

796228 A totally deflated lung's CT image construction by means of extrapolated deformable registration [7962-79]

A. Sadeghi Naini, Univ. of Western Ontario (Canada) and Robarts Research Institute (Canada) and Lawson Health Research Institute (Canada); R. V. Patel, Univ. Of Western Ontario (Canada) and Lawson Health Research Institute (Canada); A. Samani, Univ. of Western Ontario (Canada) and Robarts Research Institute (Canada) 
796229 An automated pipeline for cortical surface generation and registration of the cerebral cortex [7962-80]

W. Li, Univ. of lowa (United States); L. Ibanez, Kitware, Inc. (United States); A. Gelas, Harvard Medical School (United States); B. T. T. Yeo, Harvard Univ. (United States); M. Niethammer, Univ. of North Carolina at Chapel Hill (United States); N. C. Andreasen, V. A. Magnotta, The Univ. of lowa (United States)

7962 2A Groupwise consistent image registration: a crucial step for the construction of a standardized near infrared hyper-spectral teeth database [7962-81]

Ž. Špiclin, P. Usenik, M. Bürmen, A. Fidler, F. Pernuš, B. Likar, Univ. of Ljubljana (Slovenia)

\section{POSTER SESSION: SEGMENTATION}

7962 2B Model-based segmentation of the facial nerve and chorda tympani in pediatric CT scans [7962-82]

F. A. Reda, J. H. Noble, A. Rivas, R. F. Labadie, B. M. Dawant, Vanderbilt Univ. (United States)

7962 2C Estimation of sufficient signal to noise ratio for texture analysis of magnetic resonance images [7962-83]

S. Savio, L. Harrison, Tampere Univ. Hospital (Finland) and Tampere Univ. of Technology (Finland); P. Ryymin, P. Dastidar, S. Soimakallio, Tampere Univ. Hospital (Finland); H. Eskola, Tampere Univ. Hospital (Finland) and Tampere Univ. of Technology (Finland)

7962 2D Variational level-set segmentation and tracking of left ventricle using field prior [7962-84] M. Afshin, The Univ. of Western Ontario (Canada) and Robarts Research Institute (Canada); I. Ben Ayed, GE Healthcare (Canada); A. Islam, St. Joseph's Health Care London (Canada); I. Ross, London Health Sciences Ctr. (Canada); T. Peters, Robarts Research Institute (Canada) and The Univ. of Western Ontario (Canada); S. Li, GE Healthcare (Canada) and The Univ. of Western Ontario (Canada)

$79622 \mathrm{E} \quad$ A novel segmentation method to identify left ventricular infarction in short-axis composite strain-encoded magnetic resonance images [7962-85]

A. O. Algohary, Diagnosoft, Inc. (United States); M. K. Metwally, Nile Univ. (Egypt); A. M. El-Bialy, A. H. Kandil, Cairo Univ. (Egypt); N. F. Osman, Johns Hopkins Univ. (United States)

$79622 \mathrm{~F} \quad$ Automated analysis of infarct heterogeneity on delayed enhancement magnetic resonance images [7962-86]

Y. Lu, G. A. Paul, Sunnybrook Health Sciences Ctr. (Canada); K. A. Connelly, Univ. of Toronto (Canada) and Sunnybrook Health Sciences Ctr. (Canada); G. A. Wright, Sunnybrook Health Sciences Ctr. (Canada) and Univ. of Toronto (Canada); P. E. Radau, Sunnybrook Health Sciences Ctr. (Canada)

7962 2G White matter lesion segmentation using machine learning and weakly labeled MR images [7962-87]

Y. Xie, Univ.of Florida (United States); X. Tao, GE Global Research Ctr. (United States)

$79622 \mathrm{H} \quad$ Fast 4D segmentation of large datasets using graph cuts [7962-88]

H. Lombaert, Ecole Polytechnique de Montréal (Canada); Y. Sun, Siemens Corp. Research (United States); F. Cheriet, Ecole Polytechnique de Montréal (Canada) 


\section{Part Two}

$796221 \quad$ Segmentation of liver and liver fumor for the Liver-Workbench [7962-89]

J. Zhou, A*STAR Institute for Infocomm Research (Singapore); F. Ding, W. Xiong, National Univ. of Singapore (Singapore); W. Huang, Q. Tian, Z. Wang, A*STAR Institute for Infocomm Research (Singapore); S. K. Venkatesh, W. K. Leow, National Univ. of Singapore (Singapore)

7962 2J Automatic detection, segmentation and characterization of retinal horizontal neurons in large-scale 3D confocal imagery [7962-90]

M. Karakaya, The Univ. of Tennessee (United States); R. A. Kerekes, S. S. Gleason, Oak Ridge National Lab. (United States); R. A. P. Martins, Univ. Federal do Rio de Janeiro (Brazil); M. A. Dyer, St. Jude Children's Research Hospital (United States)

7962 2K 3D segmentation of prostate ultrasound images using wavelet transform [7962-91] H. Akbari, X. Yang, L. V. Halig, B. Fei, Emory Univ. (United States)

7962 2L Orientation estimation of anatomical structures in medical images for object recognition [7962-92]

U. Bağci, National Institutes of Health (United States); J. K. Udupa, The Univ. of Pennsylvania Health System (United States); X. Chen, National Institutes of Health (United States)

$79622 \mathrm{~N}$ Local morphologic scale: application to segmenting tumor infiltrating lymphocytes in ovarian cancer TMAs [7962-94]

A. Janowczyk, Rutgers Univ. (United States) and Indian Institute of Technology Bombay (India); S. Chandran, Indian Institute of Technology Bombay (India); M. Feldman, Hospital at the Univ. of Pennsylvania (United States); A. Madabhushi, Rutgers Univ. (United States)

796220 Brain tumour segmentation and tumour tissue classification based on multiple MR protocols [7962-95]

A. Franz, S. Remmele, J. Keupp, Philips Research Labs. (Germany)

7962 2P Confidence-based ensemble for GBM brain tumor segmentation [7962-96]

J. Huo, E. M. van Rikxoort, Univ. of California, Los Angeles (United States); K. Okada, San Francisco State Univ. (United States); H. J. Kim, W. Pope, J. Goldin, M. Brown, Univ. of California, Los Angeles (United States)

$79622 \mathrm{~F} \quad$ Feature-driven model-based segmentation [7962-97]

A. A. Qazi, J. Kim, D. A. Jaffray, Princess Margaret Hospital (Canada); V. Pekar, Philips Research North America (Canada)

$79622 R \quad C e l l$ nuclei segmentation for histopathological image analysis [7962-98]

H. Kong, K. Belkacem-Boussaid, M. Gurcan, Ohio State Univ. (United States)

7962 2S Automatic ROI identification for fast liver fumor segmentation using graph-cuts [7962-99] K. Drechsler, M. Strosche, C. Oyarzun Laura, Fraunhofer-Institut für Graphische Datenverarbeitung (Germany) 
7962 2T Simultaneous automatic detection of optic disc and fovea on fundus photographs [7962-100]

X. Xu, M. K. Garvin, The Univ. of lowa (United States); M. D. Abràmoff, The Univ. of lowa (United States) and The Veteran's Administration Medical Ctr. (United States);

J. M. Reinhardt, The Univ. of lowa (United States)

$79622 \mathrm{U}$ Supervised segmentation methods for the hippocampus in MR images [7962-101] M. van Stralen, M. I. Geerlings, K. L. Vincken, J. P. W. Pluim, Univ. Medical Ctr. Utrecht (Netherlands)

$79622 \mathrm{~V}$ Integrating an adaptive region-based appearance model with a landmark-free statistical shape model: application to prostate MRI segmentation [7962-102]

R. Toth, Rutgers, The State Univ. of New Jersey (United States); J. Bulman, A. D. Patel, Beth Israel Deaconess Medical Ctr. (United States); B. N. Bloch, Boston Medical Ctr. (United States); E. M. Genega, N. M. Rofsky, R. E. Lenkinski, Beth Israel Deaconess Medical Ctr. (United States); A. Madabhushi, Rutgers, The State Univ. of New Jersey (United States)

7962 W Segmenting multiple overlapping objects via a hybrid active contour model incorporating shape priors: applications to digital pathology [7962-103]

S. Ali, A. Madabhushi, Rutgers, The State Univ. of New Jersey (United States)

7962 2X Automatic three-dimensional rib centerline extraction from CT scans for enhanced visualization and anatomical context [7962-104] S. Ramakrishnan, Volt Workforce Solutions Inc. (United States); C. Alvino, L. Grady, A. Kiraly, Siemens Corp. Research (United States)

$79622 \mathrm{Y}$ Segmentation of in vivo target prior to tracking [7962-105]

N. Masson, P. Zanne, F. Nageotte, M. de Mathelin, LSIIT UMR CNRS, Strasbourg Univ. (France)

$79622 Z$ Stability based validation of cellular segmentation algorithms [7962-106]

P. Ajemba, R. Scott, M. Donovan, G. Fernandez, Aureon Biosciences, Inc. (United States)

796230 Neural stem cell tracking with phase contrast video microscopy [7962-107]

S. U. Rigaud, IPAL, UMI, CNRS (Singapore) and Univ. of Pierre et Marie Curie (France); N. Loménie, IPAL, UMI, CNRS (Singapore) and Ctr. National de la Recherche Scientifique (France) and Univ. Paris Descartes (France)

796231 Boundary detection by linear programming with application to lung fields segmentation [7962-108]

B. Ibragimov, B. Likar, F. Pernuš, Univ. of Ljubljana (Slovenia)

796232 A liver segmentation approach in contrast-enhanced CT images with patient-specific knowledge [7962-109]

A. Afifi, T. Nakaguchi, N. Tsumura, Chiba Univ. (Japan)

796233 Building multiple weak segmentors for strong mass segmentation in mammogram [7962-110]

Y. Zhang, N. Tomuro, J. Furst, D. S. Raicu, DePaul Univ. (United States) 
796234 A framework for automated coronary artery tracking of low axial resolution multi slice CT images [7962-111]

J. Wu, Univ. of Surrey (United Kingdom); G. Ferns, Keele Univ. (United Kingdom); J. Giles,

Conquest Hospital (United Kingdom); E. Lewis, Univ. of Surrey (United Kingdom)

796235 3D segmentation of medical volume image using hybrid level set method [7962-112] M. Lee, W. Cho, S. Kim, Y. Chen, S. Kim, Chonnam National Univ. (Korea, Republic of)

796236 Brain MRI segmentation and lesion detection using generalized Gaussian and Rician modeling [7962-113]

X. Wu, Univ. of Houston (United States); S. Bricq, C. Collet, LSIIT, UMR, CNRS, Univ. de Strasbourg (France)

796237 Robust method for extracting the pulmonary vascular trees from 3D MDCT images [7962-114]

P. Taeprasartsit, W. E. Higgins, The Pennsylvania State Univ. (United States)

796238 A computerized scheme for localization of vertebral bodies on body CT scans [7962-115] T. Hayashi, H. Chen, K. Miyamoto, X. Zhou, T. Hara, Gifu Univ. Graduate School of Medicine (Japan); R. Yokoyama, M. Kanematsu, Gifu Univ. Graduate School of Medicine and Univ. Hospital (Japan); H. Hoshi, H. Fujita, Gifu Univ. Graduate School of Medicine (Japan)

796239 Unsupervised segmentation of ultrasound images by fusion of spatio-frequential textural features [7962-116]

S. Benameur, Eiffel Medtech, Inc. (Canada); M. Mignotte, Univ. de Montréal (Canada); F. Lavoie, Eiffel Medtech, Inc. (Canada)

$79623 \mathrm{~A}$ Nonlinear band expansion and nonnegative matrix underapproximation for unsupervised segmentation of a liver from a multi-phase $\mathrm{CT}$ image [7962-117]

I. Kopriva, Ruđer Bošković Institute (Croatia); X. Chen, J. Yao, National Institutes of Health (United States)

$79623 \mathrm{~B}$ Automatic segmentation of chromatographic images for region of interest delineation [7962-118]

A. M. Mendonça, A. V. Sousa, Univ. do Porto (Portugal); M. C. Sá-Miranda, IBMC - Instituto de Biologia Molecular e Celular (Portugal); A. C. Campilho, Univ. do Porto (Portugal)

7962 3C A nonparametric segmentation method based on structural information using level sets [7962-119]

Y. Zhu, Syracuse Univ. (United States); S. Cheng, Univ. of Oklahoma, Tulsa (United States);

A. Goel, Syracuse Univ. (United States)

7962 3D Simultaneous image segmentation and medial structure estimation: application to 2D and 3D vessel tree extraction [7962-120]

S. Makram-Ebeid, J. Stawiaski, Philips Healthcare Research Lab, (France); G. Pizaine, Philips Healthcare Research Lab. (France) and Telecom ParisTech, CNRS LTCI (France) 
7962 3E A unified framework for concurrent detection of anatomical landmarks for medical image understanding [7962-121]

M. Nemoto, Y. Masutani, The Univ. of Tokyo (Japan); S. Hanaoka, The Univ. of Tokyo (Japan) and The Health and Life Science Univ. Hall in Tirol (Austria); Y. Nomura, T. Yoshikawa,

N. Hayashi, N. Yoshioka, K. Ohtomo, The Univ. of Tokyo (Japan)

$79623 \mathrm{~F} \quad$ Automatic classification for mammogram backgrounds based on bi-rads complexity definition and on a multi content analysis framework [7962-122]

J. Wu, Univ. of Technology of Compiègne (France); Q. Besnehard, C. Marchessoux, Barco

N.V. (Belgium)

$79623 \mathrm{G}$ Foibles, follies, and fusion: assessment of statistical label fusion techniques for web-based collaborations using minimal training [7962-123]

A. J. Asman, A. G. Scoggins, Vanderbilt Univ. (United States); J. L. Prince, The Johns Hopkins Univ. (United States); B. A. Landman, Vanderbilt Univ. (United States) and The Johns Hopkins Univ. (United States)

$79623 \mathrm{H} \quad$ Automatic tissue classification for high-resolution breast $\mathrm{CT}$ images based on bilateral filtering [7962-124]

X. Yang, I. Sechopoulos, B. Fei, Emory Univ. (United States)

796231 Automated cell-analysis tool for a genome-wide RNAi screen with support vector machine based supervised learning [7962-125]

S. Remmele, Univ. of Heidelberg (Germany); J. Ritzerfeld, W. Nickel, Heidelberg Univ.

Biochemistry Ctr. (Germany); J. Hesser, Univ. of Heidelberg (Germany)

7962 3J Automatic detection of regions of interest in mammographic images [7962-126]

E. Cheng, H. Ling, Temple Univ. (United States); P. R. Bakic, A. D. A. Maidment, The Univ. of Pennsylvania (United States); V. Megalooikonomou, Temple Univ. (United States)

7962 3K Plexiform neurofibroma tissue classification [7962-127]

L. Weizman, L. Hoch, The Hebrew Univ. of Jerusalem (Israel); L. Ben Sira, Tel Aviv Sourasky

Medical Ctr. (Israel); L. Joskowicz, The Hebrew Univ. of Jerusalem (Israel); L. Pratt,

S. Constantini, D. Ben Bashat, Tel Aviv Sourasky Medical Ctr. (Israel)

7962 3L A novel classification method based on membership function [7962-128]

Y. Peng, Shanghai Univ. (China); C. Shen, L. Wang, G. Zhang, East China Normal Univ. (China)

7962 3M Automatic 3D kidney segmentation based on shape constrained GC-OAAM [7962-129]

X. Chen, R. M. Summers, J. Yao, National Institutes of Health (United States)

$79623 \mathrm{~N} \quad$ A new steerable pressure force for parametric deformable models [7962-130] J. Kong, L. Cooper, A. Sharma, T. Kurc, D. Brat, J. Saltz, Emory Univ. (United States)

796230 Towards a parts-based approach to sub-cortical brain structure parsing [7962-131]

D. Gagneja, SUNY at Buffalo (United States) and Indian Institute of Technology, Kharagpur (India); C. Xiong, J. J. Corso, SUNY at Buffalo (United States) 
$79623 \mathrm{P}$ Region based level set segmentation of the outer wall of the carotid bifurcation in CTA [7962-132]

D. Vukadinovic, T. van Walsum, R. Manniesing, S. Rozie, A. van der Lugt, Erasmus MC, Univ. Medical Ctr. Rotterdam (Netherlands); W. J. Niessen, Erasmus MC, Univ. Medical Ctr. Rotterdam (Netherlands) and Delft Univ. of Technology (Netherlands)

$79623 Q \quad$ Implicit medial representation for vessel segmentation [7962-133]

G. Pizaine, Philips Healthcare (France) and Telecom ParisTech, CNRS (France); E. Angelini,

I. Bloch, Telecom ParisTech, CNRS (France); S. Makram-Ebeid, Philips Healthcare (France)

7962 3R A study on automated anatomical labeling to arteries concerning with colon from 3D abdominal CT images [7962-134]

B. H. Hoang, M. Oda, Z. Jiang, Nagoya Univ. (Japan); T. Kitasaka, Aichi Institute of Technology (Japan); K. Misawa, Aichi Cancer Ctr. (Japan); M. Fujiwara, K. Mori, Nagoya Univ. (Japan)

796235 Direction-dependent level set segmentation of cerebrovascular structures [7962-135]

N. D. Forkert, D. Säring, T. Illies, J. Fiehler, Univ. Medical Ctr. Hamburg-Eppendorf (Germany);

J. Ehrhardt, H. Handels, A. Schmidt-Richberg, Univ. of Lübeck (Germany)

$79623 \mathrm{U}$ Evaluation of blood vessel detection methods [7962-137]

R. Sadeghzadeh, M. Berks, S. M. Astley, C. J. Taylor, The Univ. of Manchester (United Kingdom)

7962 3V Automatic segmentation and diameter measurement of coronary artery vessels [7962-138] K. Zhao, Z. Tang, J. Pauli, Univ. of Duisburg-Essen (Germany)

\section{POSTER SESSION: CLASSIFICATION}

7962 3W Liver fat quantification using fast $\mathrm{kVp}$-switching dual energy CT [7962-139]

A. Kriston, GE Healthcare (Hungary); P. Mendonça, GE Global Research (United States); A. Silva, R. G. Paden, W. Pavlicek, Mayo Clinic Scottsdale (United States); D. Sahani, Massachusetts General Hospital (United States); B. Janos Kis, Univ. of Szeged (Hungary); L. Rusko, GE Healthcare (Hungary); D. Okerlund, GE Healthcare (United States); R. Bhotika, GE Global Research (United States)

7962 3X Robust biological parametric mapping: an improved technique for multimodal brain image analysis [7962-140]

X. Yang, Vanderbilt Univ. (United States); L. Beason-Held, S. M. Resnick, National Institutes of Health (United States); B. A. Landman, Vanderbilt Univ. (United States) and The John Hopkins Univ. (United States)

$79623 Y \quad$ Automatic assessment of ultrasound image usability [7962-141]

L. Valente, G. Funka-Lea, Siemens Corp. Research (United States); J. Stoll, Siemens Healthcare (United States)

796232 An image-guided tool to prevent hospital acquired infections [7962-142] M. Nagy, L. Szilágyi, Á. Lehotsky, T. Haidegger, B. Benyó, Budapest Univ. of Technology and Economics (Hungary) 
796240 Propagating uncertainties in statistical model based shape prediction [7962-143] E. Syrkina, R. Blanc, G. Székely, ETH Zurich (Switzerland)

796241 Shape model training for concurrent localization of the left and right knee [7962-144] H. Ruppertshofen, Univ. of Applied Sciences Kiel (Germany) and Otto-von-Guericke Univ. Magdeburg (Germany); C. Lorenz, Philips Research Labs. (Germany); S. Schmidt, Univ. of Applied Sciences (Germany) and Otto-von-Guericke Univ. Magdeburg (Germany); P. Beyerlein, Univ. of Applied Sciences Wildau (Germany); Z. Salah, G. Rose, Otto-von-Guericke Univ. Magdeburg (Germany); H. Schramm, Univ. of Applied Sciences Kiel (Germany)

796242 Whole vertebral bone segmentation method with a statistical intensity-shape model based approach [7962-145]

S. Hanaoka, The Health and Life Sciences Univ. (Austria) and The Univ. of Tokyo Hospital (Japan); K. Fritscher, B. Schuler, The Health and Life Sciences Univ. (Austria); Y. Masutani, N. Hayashi, K. Ohtomo, The Univ. of Tokyo Hospital (Japan); R. Schubert, The Health and Life Sciences Univ. (Austria)

796243 Detecting hippocampal shape changes in Alzheimer's disease using statistical shape models [7962-146]

K. Shen, Australian e-Health Research Ctr. (Australia) and LE2I, CNRS, Univ. de Bourgogne (France); P. Bourgeat, J. Fripp, Australian e-Health Research Ctr. (Australia); F. Meriaudeau, LE2I, CNRS, Univ. de Bourgogne (France); O. Salvado, Australian e-Health Research Ctr. (Australia)

796244 Classification of mathematics deficiency using shape and scale analysis of 3D brain structures [7962-147]

S. Kurtek, E. Klassen, The Florida State Univ. (United States); J. C. Gore, Z. Ding, Vanderbilt Univ. (United States); A. Srivastava, The Florida State Univ. (United States)

796245 A decision support scheme for vertebral geometry on body CT scans [7962-148] T. Hayashi, H. Chen, Gifu Univ. (Japan); K. Miyamoto, Gifu Univ. Graduate School of Medicine (Japan); X. Zhou, T. Hara, Gifu Univ. (Japan); R. Yokoyama, M. Kanematsu, Graduate School of Medicine and Univ. Hospital (Japan); H. Hoshi, H. Fujita, Gifu Univ. (Japan)

796246 A joint model for boundaries of multiple anatomical parts [7962-149] G. Kerr, INRIA (France); S. Kurtek, A. Srivastava, Florida State Univ. (United States)

796247 Global-to-local, shape-based, real and virtual landmarks for shape modeling by recursive boundary subdivision [7962-150] S. Rueda, The Univ. of Oxford (United Kingdom); J. K. Udupa, The Univ. of Pennsylvania (United States)

796248 Automatic cortical thickness analysis on rodent brain [7962-151] J. Lee, The Univ. of North Carolina at Chapel Hill (United States); C. Ehlers, Scripps Research Institute (United States); F. Crews, M. Niethammer, F. Budin, B. Paniagua, K. Sulik, J. Johns, M. Styner, I. Oguz, The Univ. of North Carolina at Chapel Hill (United States) 
796249 Statistical modeling of the arterial vascular tree [7962-152]

T. Beck, C. Godenschwager, M. Baver, Karlsruher Institut für Technologie (Germany) and Siemens AG (Germany); D. Bernhardt, Siemens AG (Germany); R. Dillmann, Karlsruher Institut für Technologie (Germany)

\section{POSTER SESSION: MOTION ANALYSIS}

7962 4A Motion tracking of left ventricle and coronaries in 4D CTA [7962-153]

D. P. Zhang, Imperial College London (United Kingdom); X. Zhuang, S. Ourselin, Univ. College London (United Kingdom); D. Rueckert, Imperial College London (United Kingdom)

7962 4B Three-dimensional kinematic estimation of mobile-bearing total knee arthroplasty from $x$-ray fluoroscopic images [7962-154]

T. Yamazaki, K. Futai, T. Tomita, Y. Sato, H. Yoshikawa, S. Tamura, K. Sugamoto, Osaka Univ. Graduate School of Medicine (Japan)

7962 4C An iterative particle filter approach for respiratory motion estimation in nuclear medicine imaging (Cum Laude Poster Award) [7962-155]

A. A. Abd. Rahni, K. Wells, E. Lewis, Univ. of Surrey (United Kingdom); M. Guy, Southampton Univ. Hospital Trust (United Kingdom); B. Goswami, Univ. of Surrey (United Kingdom)

7962 4D SLIMMER: SLIce MRI motion estimation and reconstruction tool for studies of fetal anatomy [7962-156]

K. Kim, P. A. Habas, V. Rajagopalan, J. Scott, Univ. of California, San Francisco (United States); F. Rousseau, LSIIT, CNRS, Univ. of Strasbourg (France); A. J. Barkovich, O. A. Glenn, C. Studholme, Univ. of California, San Francisco (United States)

$79624 \mathrm{E}$ Development of an automated processing method to detect still timing of cardiac motion for coronary magnetic resonance angiography [7962-158]

H. Asou, Tsuchiya General Hospital (Japan) and Kanazawa Univ. Graduate School of Medical Sciences (Japan); K. Ichikawa, Kanazawa Univ. Graduate School of Medical Sciences (Japan); N. Imada, T. Masuda, T. Satou, Tsuchiya General Hospital (Japan)

\section{POSTER SESSION: DTI AND FUNCTION}

$79624 \mathrm{~F}$ Shape anisotropy: tensor distance to anisotropy measure [7962-159]

Y. T. Weldeselassie, S. El-Hilo, M. S. Atkins, Simon Fraser Univ. (Canada)

7962 4G Scalable brain network construction on white matter fibers [7962-160] M. K. Chung, Univ. of Wisconsin-Madison (United States) and Waisman Lab. for Brain Imaging (United States) and Seoul National Univ. (Korea, Republic of); N. Adluru, K. M. Dalton, A. L. Alexander, R. J. Davidson, Waisman Lab. for Brain Imaging, Univ. of Wisconsin-Madison (United States)

$79624 \mathrm{H} \quad$ Comparison between fourth and second order DT-MR image segmentations [7962-161] S. El-Hilo, Y. T. Weldeselassie, M. S. Atkins, Simon Fraser Univ. (Canada)

$796241 \quad$ Second order DTMR image segmentation using random walker [7962-162]

S. El-Hilo, Y. T. Weldeselassie, M. S. Atkins, Simon Fraser Univ. (Canada) 
$79624 \mathrm{~J}$ Effect of regularization parameter and scan time on crossing fibers with constrained compressed sensing [7962-163]

F. E. A. Elshahaby, The Johns Hopkins Univ. (United States); B. A. Landman, Vanderbilt Univ. (United States); J. L. Prince, The Johns Hopkins Univ. (United States)

7962 4K A new metric to measure shape differences in fMRI activity [7962-164]

S. Khullar, Rochester Institute of Technology (United States) and The Mind Research Network (United States); A. M. Michael, The Mind Research Network (United States); N. Correa, T. Adali, Univ. of Maryland (United States); N. Cahill, S. A. Baum, Rochester Institute of Technology (United States); V. D. Calhoun, Rochester Institute of Technology (United States) and The Mind Research Network (United States) and Univ. of New Mexico (United States)

$79624 \mathrm{~L}$ Fast computation of functional networks from fMRI activity: a multi-platform comparison [7962-165]

A. R. Rao, R. Bordawekar, G. Cecchi, IBM Thomas T.J. Watson Research Ctr. (United States)

POSTER SESSION: ENHANCEMENT

7962 4M Defector defect correction of medical images on graphics processors [7962-166]

R. Membarth, F. Hannig, J. Teich, Univ. of Erlangen-Nuremberg (Germany); G. Litz,

H. Hornegger, Siemens AG (Germany)

796240 Reconstruction of high-resolution fluorescence microscopy images based on axial tomography [7962-168]

S. Remmele, B. Oehm, F. Staier, H. Eipel, C. Cremer, J. Hesser, Ruprecht Karls Univ. Heidelberg (Germany)

7962 4P Improved 3-D wavelet-based de-noising of fMRI data [7962-169]

S. Khullar, Rochester Institute of Technology (United States) and The Mind Research Network (United States); A. M. Michael, The Mind Research Network (United States); N. Correa, T. Adali, Univ. of Maryland (United States); S. A. Baum, Rochester Institute of Technology (United States); V. D. Calhoun, The Mind Research Network (United States) and Rochester Institute of Technology (United States) and Univ. of New Mexico (United States)

7962 4R Phase-unwrapping of differential phase-contrast data using attenuation information [7962-172]

W. Haas, Friedrich-Alexander-Univ. Erlangen-Nürnberg (Germany); M. Bech, Technische Univ. München (Germany); P. Bartl, F. Bayer, A. Ritter, T. Weber, G. Pelzer, Friedrich-Alexander-Univ. Erlangen-Nürnberg (Germany); M. Willner, K. Achterhold, Technische Univ. München (Germany); J. Durst, T. Michel, M. Prümmer, Friedrich-Alexander-Univ. Erlangen-Nürnberg (Germany); F. Pfeiffer, Technische Univ. München (Germany); G. Anton, Friedrich-Alexander-Univ. Erlangen-Nürnberg (Germany); J. Hornegger, Friedrich-Alexander-Univ. Erlangen-Nürnberg (Germany) and Erlangen Graduate School in Advanced Optical Technologies (Germany)

$79624 S \quad$ Iterative wavelet thresholding for rapid MRI reconstruction [7962-173]

M. H. Kayvanrad, C. A. McKenzie, T. M. Peters, The Univ. of Western Ontario (Canada) and Robarts Research Institute (Canada) 
7962 4T Quantitative and qualitative image quality analysis of super resolution images from a low cost scanning laser ophthalmoscope [7962-174]

S. Murillo, S. Echegaray, G. Zamora, P. Soliz, VisionQuest Biomedical, LLC (United States);

W. Bauman, Retina Institute of South Texas (United States)

$79624 \mathrm{U}$ A maximum likelihood estimation method for denoising magnitude MRI using restricted local neighborhood [7962-176]

J. Rajan, M. Verhoye, J. Sijbers, Univ. Antwerpen (Belgium)

$79624 \mathrm{~V}$ SinoCor: a clinical tool for sinogram-level patient motion correction in SPECT [7962-177]

D. Mitra, D. Eiland, T. Walsh, Florida Institute of Technology (United States); R. Bouthcko,

G. T. Gullberg, Lawrence Berkeley National Lab. (United States); N. Schechtmann, MIMA (United States)

7962 4W Noise-resistant adaptive scale using stabilized diffusion [7962-178]

A. Souza, Carestream Health, Inc. (United States)

$79624 \mathrm{X}$ Mapping spatio-temporal filtering algorithms used in fluoroscopy to single core and multi-core DSP architectures [7962-179]

U. Dasgupta, M. Ali, Texas Instruments Inc. (United States)

Author Index 
Downloaded From: https://www.spiedigitallibrary.org/conference-proceedings-of-spie on 26 Apr 2023

Terms of Use: https://www.spiedigitallibrary.org/terms-of-use 


\title{
Conference Committee
}

\author{
Symposium Chairs
}

Maryellen L. Giger, The University of Chicago (United States)

Joseph M. Reinhardt, The University of lowa (United States)

\section{Conference Chairs}

Benoit M. Dawant, Vanderbilt University (United States)

David R. Haynor, University of Washington (United States)

Program Committee

Mostafa Analoui, The Livingston Group (United States)

Kyongtae T. Bae, University of Pittsburgh Medical Center (United States)

Christian Barillot, Institut de Recherche en Informatique et Systèmes Aléatoires (France)

Baowei Fei, Emory University (United States)

Aaron Fenster, Robarts Research Institute (Canada)

Bernd Fischer, Fraunhofer MEVIS (Germany)

Alejandro F. Frangi, Universitat Pompeu Fabra (Spain)

Mona K. Garvin, The University of lowa (United States)

James C. Gee, University of Pennsylvania (United States)

Guido Gerig, The University of Utah (United States)

Tobias Heimann, Deutsches Krebsforschungszentrum (Germany)

Tianhu Lei, The Children's Hospital of Philadelphia (United States)

Boudewijn P. F. Lelieveldt, Leids University Medical Center (Netherlands)

Boštjan Likar, University of Ljubljana (Slovenia)

Murray H. Loew, The George Washington University (United States)

Cristian Lorenz, Philips Research (Germany)

Frederik Maes, Katholieke Universiteit Leuven (Belgium)

Vincent A. Magnotta, The University of lowa Hospitals and Clinics (United States)

Sunanda D. Mitra, Texas Tech University (United States)

Kensaku Mori, Nagoya University (Japan)

Nassir Navab, Technische Universität München (Germany)

Mads Nielsen, University of Copenhagen (Denmark)

Wiro J. Niessen, Erasmus MC (Netherlands)

Sébastien Ourselin, University College London (United Kingdom)

Josien P. W. Pluim, Universitair Medisch Centrum Utrecht (Netherlands)

Daniel Rueckert, Imperial College London (United Kingdom)

Punam K. Saha, The University of lowa (United States)

Olivier Salvado, Commonwealth Scientific and Industrial Research

Organisation (Australia) 
Julia A. Schnabel, University of Oxford (United Kingdom)

Colin Studholme, University of California, San Francisco (United States)

Martin A. Styner, The University of North Carolina at Chapel Hill (United States)

Philippe Thévenaz, Ecole Polytechnique Fédérale de Lausanne (Switzerland)

Jayaram K. Udupa, The University of Pennsylvania Health System (United States)

Andreas Wahle, The University of lowa (United States)

\section{Session Chairs}

$1 \quad$ Keynote and Segmentation I

Mona K. Garvin, The University of lowa (United States)

2 Cardiac Applications

Wiro J. Niessen, Erasmus MC (Netherlands)

3 Skeletal and Orthopedic Applications

Punam K. Saha, The University of lowa (United States)

$4 \quad 2 \mathrm{D}$ Image Analysis

Murray H. Loew, The George Washington University (United States)

$5 \quad$ Brain Structure and DTI

Vincent A. Magnotta, The University of lowa Hospitals and Clinics (United States)

6 Registration I

Josien P. W. Pluim, Universitair Medisch Centrum Utrecht (Netherlands)

$7 \quad$ Shape Methods and Applications

Sébastien Ourselin, University College London (United Kingdom)

8 Segmentation II

Aaron Fenster, Robarts Research Institute (Canada)

9 Registration II

Bernd Fischer, Fraunhofer MEVIS (Germany)

10 Image Enhancement/Classification

Tianhu Lei, The Children's Hospital of Philadelphia (United States)

11 Segmentation of Vascular Images

Boudewijn P. F. Lelieveldt, Leids University Medisch Center (Netherlands) 